\title{
Health- and skill-related physical fitness profile of Brazilian children and adolescents: a systematic review
}

\author{
Perfil da aptidão física relacionada à saúde e ao desempenho motor de crianças e \\ adolescentes brasileiros: uma revisão sistemática
}

\begin{abstract}
AUTHOR'S
Augusto Pedretti ${ }^{1,2}$ (D)

Júlio Brugnara Mello ${ }^{1,3}$ (D)

Anelise Reis Gaya ${ }^{1}$ (D)

Alessandro Pedretti ${ }^{4}$ (D)

Adroaldo Gaya ${ }^{1}$ (D)

1 Projeto Esporte Brasil. Programa de Pósgraduação em Ciências do Movimento Humano. Universidade Federal do Rio Grande do Sul, Faculdade de Educação Física, Fisioterapia e Dança, Porto Alegre, Rio Grande do Sul, Brasil. 2 Universidade Regional do Cariri, Departamento de Educação Física, Crato, Ceará, Brasil.

3 Faculdade Sogipa, Departamento de Educação Física, Porto Alegre, Rio Grande do Sul, Brasil. 4 Escola Municipal Newton Tavares, Boa Vista, Roraima, Brasil.
\end{abstract}

\section{CORRESPONDING}

\section{Adroaldo Gaya}

\section{acgaya@esef.ufrgs.br}

Projeto Esporte Brasil. Escola de Educação

Física, Fisioterapia e Dança da UFRGS.

Rua Felizardo no 750 - sala 205 do LAPEX.

Bairro Jardim Botânico, Porto Alegre, Rio

Grande do Sul, Brasil.

CEP: 90690-200.

DOI

10.12820/rbafs. $25 \mathrm{e} 0131$

\section{(cc) BY}

This work is licensed under a Creative Commons Attribution 4.0 International License.

\begin{abstract}
Since 1994, the Projeto Esporte Brasil (PROESP-Br) battery tests has been used to evaluate healthand skill-related physical fitness among aged 6-17 Brazilian schoolchildren. The aim of this study was to delineate the Brazilian children and youth's physical fitness profile from a systematic review over studies that used the PROESP-Br proposal. The search was carried at PubMed, ScienceDirect, Lilacs, SciELO and Google Scholar. Original studies published between 1994 and 2017 about physical fitness (health and/or motor performance) with schoolchildren (children and/or adolescents) that used the PROESP-Br battery test were included. A total of 13.582 participants were evaluated to health-related fitness and 276 to skill-related fitness from 18 included studies. The methodological quality was evaluated using the Newcastle-Ottawa quality assessment scale adapted version. The results show that $27-30 \%$ of youngsters are at health "risk zone" for Body Mass Index (BMI), $70 \%$ for cardiorespiratory fitness (CRF), $50 \%$ and $65 \%$ for flexibility (FLEX) and muscular strength (MST), respectively. The data concerning skill-related fitness were inconsistent. In summary, the results suggest that Brazilian children and adolescents have low cardiovascular health level (BMI/ $\mathrm{CRF}$ ), mainly regarding CRF, and low muscle health level (FLEX/MST). We emphasize that the lack of studies regarding skill-related fitness, make it impossible to describe the profile of the components of this construct.
\end{abstract}

Keywords: Physical education; School; Physical fitness; Children; Adolescents.

RESUMO

O Projeto Esporte Brasil (PROESP-Br) propõe, desde 1994, uma bateria de medidas e testes para avaliação de escolares entre seis e 17 anos com o objetivo de delinear o perfil de crianças e jovens brasileiros no que se refere a aptidão física relacionada à saúde e ao desempenho motor. $O$ objetivo deste estudo foi delinear - perfil da aptidão física de crianças e jovens brasileiros a partir de uma revisão sistemática da literatura sobre artigos que utilizaram da proposta do PROESP-Br. A busca foi realizada na PubMed, ScienceDirect, Lilacs, SciELO e Google Acadêmico. Estudos originais publicados entre 1994 e 2017 acerca da aptidão física (saúde elou desempenho motor) de escolares (crianças elou adolescentes) que utilizaram a bateria de testes do PROESP-Br foram incluídos. Um total de 13.582 sujeitos foram avaliados quanto a saúde e 276 quanto ao desempenho motor nos 18 estudos incluídos. A qualidade metodológica foi avaliada uma versão adaptada da Newcastle-Ottawa quality assessment scale. Os resultados evidenciam que 27-30\% dos jovens estão na "zona de risco" à saúde para o Índice de Massa Corporal (IMC), 70\% para a aptidão cardiorrespiratória $(A p C)$ e 50 e 65\% para flexibilidade e força muscular localizada (FML), respectivamente. Os dados sobre o desempenho motor são inconsistentes nesta revisão de literatura. Em sintese, os resultados indicam baixos niveis de saúde cardiovascular (IMC/ApC), principalmente quanto à $A p C$, assim como baixos níveis de saúde musculoesquelética (flexibilidade/FML) dos jovens. Ressalta-se a escassez de estudos quanto ao desempenho motor impossibilitando delinear o perfil dos componentes deste construto.

Palavras-chave: Educação física; Escola; Aptidão física; Criança; Adolescente.

\section{Introduction}

Twenty-four years ago, the professor Adroaldo Gaya ${ }^{1}$ asked himself: "But after all, what is Physical Education (PE)?". Many years passed and we do not know if actual $\mathrm{PE}$ programs has been contributed to the development physical fitness of Brazilian children and adolescents. There are few Brazilian states (from the
26 and the Federal District) that have PE as a mandatory subject at the school program in Brazil. In primary school (3-5 years old), basic school (6-14 years old) and high school (15-17 years old) it is necessary to recognize the PE teacher's relevance for the growth and body development of children and adolescents.

Meanwhile, we observed at the Student Health 
National Research ${ }^{2}$, that on average $34 \%$ of adolescents were physically active, $61 \%$ insufficiently active and 5\% physically inactive. Likewise, the Brazil Human Development National Report ${ }^{3}$ shows that only $0.55 \%$ of the Brazilian public and private schools have a culture and infrastructure which values and promote physical activities and sports. That is, nearly $88 \%$ of the schools present very poor conditions to promote physical activities and sports, being $12 \%$ at intermediate levels.

We believe that PE classes should be directed to influence positively the students' health- and skill-related fitness levels and motor development linked to $\mathrm{PE}$ specific contents (gymnastic components, rhythmic activities, motor abilities and sporting games). This perspective of school transformation, in the scope of health promotion, may help children to become more active, as well as to affect positively all the school community ${ }^{4}$.

Another relevant question is should we be interested only in developing elite young athletes? $?^{5}$. It would seem intuitively naive to ignore the potential benefits of long-term athletic development as a way to improve physical fitness and health of children and adolescents $^{6}$. Some researchers argue that, for global benefits, the long-term athletic development programs are not only appropriate but also essential to all adolescents ${ }^{7}$. A proper motor development at younger ages, gives in the future equal opportunity of choice to everyone, within the multiple values and meanings of physical activity, related to health, skills, competition, socialization and leisure, among others ${ }^{3}$.

Research systematically shows the positive effects of many school-programs, promoting the students' interest for physical activity and sport along with health-related ${ }^{8}$ and skill-related physical fitness ${ }^{9}$. Janssen and LeBlanc ${ }^{8}$ showed that physical activity is positively associated with health indicators in school-age children and youth, like better profiles in blood cholesterol, blood pressure, metabolic syndrome, obesity prevention and bone density. García-Hermoso et al. ${ }^{9}$ observed a negative association between muscular fitness during childhood/adolescence and adiposity and cardiometabolic parameters in adulthood, together with a positive association for bone health.

The Projeto Esporte Brasil (PROESP-Br) is a health- and skills-related physical fitness evaluation system of children and adolescents. With the ambition to be a PE teacher's tool, the PROESP-Br developed a battery test easy to access, at a very low cost, with a minimal requirement of sophisticated materials and easy to use, evidently maintaining the rigor of validity, reliability and objectivity. It must be pointed out that the referenced-criteria for health and skill-related fitness were established from the Brazilian population data ${ }^{10}$.

Periodic evaluation of the physical fitness is an essential activity to guide the quality of $\mathrm{PE}$ teachers' interventions, considering their pedagogical inherent commitments to promote children and adolescents' health, stimulate the establishment of active lifestyle behaviors through sports practices, popular games, gymnastics, martial arts and dance. A physical fitness evaluation allows the teacher to draw a students' diagnostic profile and observe the benefits of his/her pedagogical interventions. The development follow-up of different levels of physical fitness, in the field of health and skills, allows teachers and coaches to obtain indicators that can support quality and adequate planning to their classes and training sessions, according to the students or athlete's needs.

Therefore, the present study adds to the field by delineating a profile of health-related fitness and skills-related fitness through a systematic review on articles that included the battery of tests and measures proposed by the PROESP-Br.

\section{Methods}

This systematic review was conducted according to the Preferred Reporting Items for Systematic Reviews and Meta-Analyses (The PRISMA Statement) ${ }^{11}$ and registered at the International Prospective Register of Systematic Reviews (PROSPERO - $\mathrm{n}^{\circ}$ CRD42017063848). We used the Health Sciences Descriptors (DeCs) and the Medical Subject Headings (MeSH), and the following descriptors were used: PROESP; physical fitness; children and adolescents. In addition, the searches were performed using Boolean operators "AND" and "OR", using the strategy in English ((PROESP) AND ("physical fitness") AND (children OR adolescent)), Spanish ((PROESP) AND ("aptitud física") AND (niño OR adolescente)) and Portuguese ((PROESP) AND ("aptidão física") AND (crianças OR adolescentes)) in each website databases. Moreover, additional research was done on the references of selected articles.

The inclusion criteria used for the study were: (i) original articles published between 1994 and 2018 wherein (ii) evaluations were conducted with PROESP-Br battery, (iii) physical fitness were evaluated (health-related or skill-related physical fitness) 
(iv) including children and/or adolescents (aged 6-17 years). Only original articles were considered for eligibility and there were no restrictions about study designs for inclusion. The exclusion criteria applied were did not use the full battery of measurements and tests for health- or skill-related physical fitness.

The search was carried in peer-reviewed journals indexed in the website databases PubMed, ScienceDirect, Lilacs, SciELO and Google Scholar. The time interval comprised the period from 1994 to 2018 (1994 represents the date that PROESP-Br started). Two researchers carried out the search in the databases and the selection of titles, abstracts and articles independently, considering the inclusion and exclusion criteria. In cases of disagreement among researchers, a third researcher was consult at consensus meetings.

The Newcastle-Ottawa quality assessment scale ${ }^{12}$ evaluate the methodological quality in cross-sectional studies for systematic reviews. The extracted components were defined by all the authors, and the scale was scored by the first two authors and checked by a third author. For this study, the authors adapted the scale removing the comparability evaluation, once it does not apply to the selected studies design. A 'star system' was developed in which a study was judged on three broad perspectives: 1) the selection of the study groups; 2) the comparability of the groups; and 3) the ascertainment of either the exposure or outcome of interest for case-control or cohort studies respectively. The comparability perspective was exclude since it does not apply to the included studies design. The adapted scale can be seen in the supplement.

The information evaluated were: the selection of the sample (describes the method and/or the procedure or not); the sample size (describes the criteria adopted for the sample calculation or not); description of the data collection procedure (describes the evaluation procedures for each study variable or not); valid cases (describes the valid and/or missing cases of the variables evaluated or not); coherence was analysed (the data analysis was consistent with the objective of the study or not); description of the data analysis procedure (the statistical procedure for data analysis was clearly described and appropriate or no; in the case of a descriptive study with a representative sample, the confidence interval or standard deviation was included or not).

For each positive identified criteria, the study earned one star, with the possibility of earning two stars in the description of the procedures, totalling seven stars.
Studies that scored five stars or more were considered to be of good methodological quality.

After the different phases of the systematic review, the extraction of the data contained in Tables 1, 2, 3 and 4 was performed by the first two authors, after defining the components to be extracted by all authors together and checked by a third author. When possible, the absolut frequency values for each study variable were stratified by sex. Then, summed up for each variable evaluated for the participants. After absolute value identifications, the relative frequencies (percentages) were calculated for health-related fitness ("health risk zone" and "healthy zone") and skill-related fitness ("regular", "good", "very good", "excellence") on each variable, always considering the total of participants at the variable and the way the result was described (stratified by sex when possible).

\section{Results}

Electronic search identified 561 potentially relevant studies and 5 additional records identified through the references of eligibility articles (PubMed $=0$; ScienceDirect $=6$; Lilacs = 41; SciELO = 11; Google Scholar = 503). Then, 353 records were deleted after checking duplicates, abstracts, dissertations and theses. Title and abstract were read and the inclusion criteria applied. A total of 213 original articles were fully analysed and 40 records excluded for not having included the PROES$\mathrm{P}-\mathrm{Br}$ battery. Thus, 173 met the eligibility criteria and 152 of full-text articles were excluded for not using the full battery for health- or skill-related fitness. From these, 18 met all the inclusion criteria. Sixteen evaluated the health-related fitness and three the skills-related to fitness. Figure 1 shows the PRISMA Flow Diagram.

A total of 13.582 participants with aged 6-17 years were submitted to the health-related fitness tests and 276 participants with aged 6-16 years were submitted to the skills-related fitness tests. Some studies did not report sample stratified by sex making it difficult to evaluate the results.

The main methodological characteristics were summarized in Table 1. Except one study (quasi-experimental), all others have an observational design. From 18 included studies, 14 of them were published from 2014-2018 and the others were published in 2013, 2012, 2011 e 2008. Concerning the Brazilian geographical regions, studies that evaluated the health-related fitness were conducted at the South (12), North (1), Northeast (1), Southeast (1) Brazilian regions and 


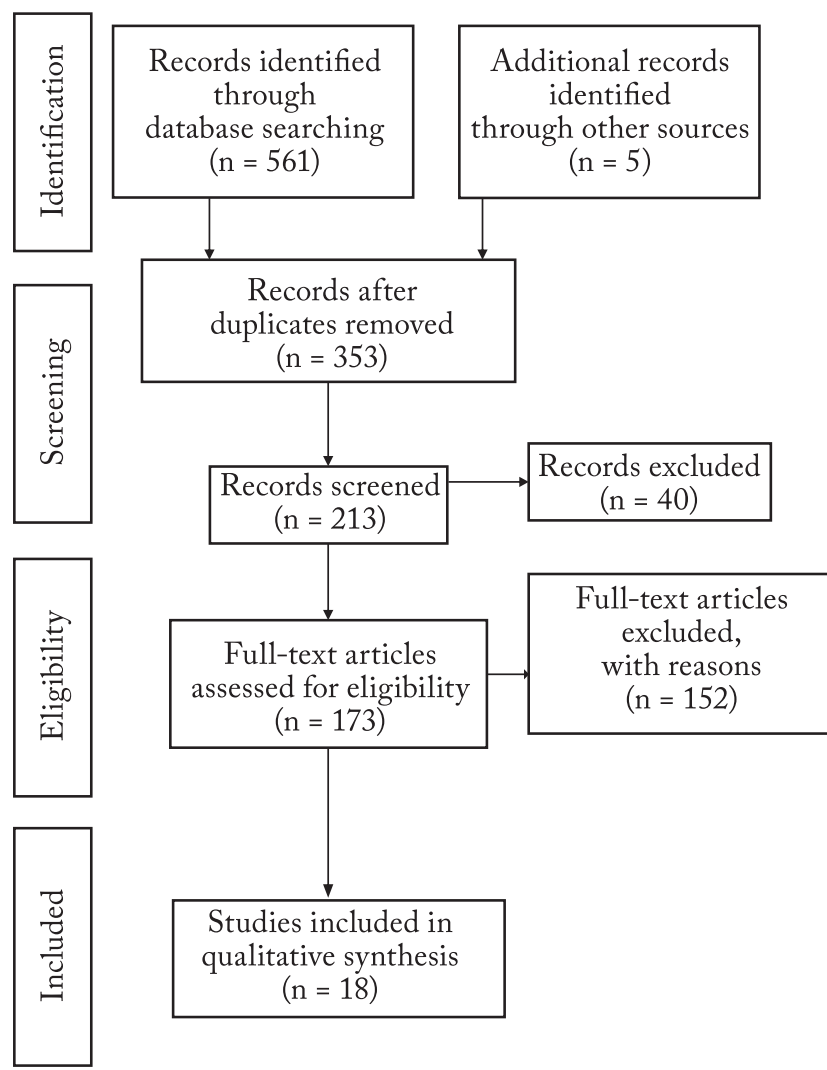

Figure 1 - PRISMA Flow Diagram.

a national sample (1). The studies that evaluated the skills-related fitness were conducted at the South (1), North (1) and Southeast (1) Brazilian regions.

Information on the physical fitness of children and adolescents were described as presented in their respective studies. To describe the cardiorespiratory fitness (CRF), flexibility (FLEX) and muscular strength (MST), 12 studies described the classification criteria suggested by PROESP-Br: "health risk zone" (RZ) and "healthy zone" (HZ). Four studies described the test results with their mean and standard deviation values. Regarding body mass index (BMI), seven studies used the criteria suggested by PROESP-Br, four studies used different criteria to classify overweight/obesity and five studies presented the mean and standard deviation values.

On a seven-star scale (five stars denoting good methodological quality), two studies were observed as having seven stars, three studies as having six stars and six studies as having five-star. Eleven out of 18 included studies showed a good methodological quality; seven scored four stars.

From the total sample, 1372 children and adolescents had their BMI evaluated and classified by
PROESP-Br criteria. The percentage of participants classified at the RZ was $30.8 \%$ (242 from 868). The studies that used a normal weight, overweight and obesity criteria evaluated 3442 participants, with $27.6 \%$ (950 from 3442) classified as overweight and obese. When stratified by sex, we observed that there was a similarity between boys and girls about overweight/ obesity and BMI at the RZ, regardless of the classification criteria.

A total of 12.196 participants were evaluated for CRF. In general, approximately 72\% (8.781 from 12.196) of the participants were classified at the RZ. When stratified by sex, similarities, approximately $76 \%$ (6.964 from 9.155), of boys and girls were classified at the RZ for CRF.

For FLEX, 12.282 participants were evaluated. In general, classifications were balanced, with 50\% (6.141 from 12.282) of the classifications in the RZ. The sex-stratified analysis showed that 50\% (2.672 from 4.915) of boys and 53\% (2.105 from 4.277) of girls were at the RZ for FLEX.

The MST was evaluated in 10.689 children and adolescents. From this total, 64.9\% (6.948 from 10.689) of participants were at the RZ. The stratified analysis by sex showed a clear difference, with $48.8 \%(2,086$ from 4.274) of girls against $74.8 \%$ (3.714 from 4.960) of boys at the RZ.

The results described in mean values (Table 3) for the four variables made the sum of the values inappropriate for the presentation of an overall mean, due to the high variability of the subject ages at the studies and the inappropriate classification about the $\mathrm{RZ}$ or the HZ.

Regarding the variables composing the skills-related fitness, each one of the authors presented their results distinctly. Moreira et al. ${ }^{13}$ was the only study that followed the PROESP-Br suggested criteria, highlighting that for upper limbs explosive strength (UES) and agility approximately $63 \%$ of the participants were at the "WEAK" category. For lower limbs explosive strength (LLES) and speed, approximately 50\% were classified as "good" and "very good". For speed, just five boys were classified as "excellence" category and for CRF $86 \%$ of the boys were classified at the "excellence" and 13\% at the "very good" categories. Those boys participated in a Sports Project with organized and planned activities.

Considering that it is inappropriate to compare the results described in mean values for five variables, due 
Table 1 - Children and adolescents' physical fitness studies characteristics.

\begin{tabular}{|c|c|c|c|c|c|c|}
\hline \multirow{2}{*}{ Study } & \multirow{2}{*}{ Region } & \multicolumn{2}{|c|}{$\mathrm{n}$} & \multirow[t]{2}{*}{ Study design } & \multirow[t]{2}{*}{$¥$} & \multirow[t]{2}{*}{ « } \\
\hline & & $\mathrm{F}$ & M & & & \\
\hline \multicolumn{7}{|c|}{ Health-related Physical Fitness } \\
\hline Barbosa $^{40}$ & Palmas, Tocantins & 9 & 11 & Observational & $\mathrm{Y}$ & 4 \\
\hline Borges $^{41}$ & Cruz Alta, Rio Grande do Sul & 43 & & Observational & $\mathrm{Y}$ & 5 \\
\hline Contreira $^{42}$ & Florianópolis, Santa Catarina & 72 & 36 & Observational & $\mathrm{Y}$ & 6 \\
\hline Dumith $^{43}$ & Rio Grande, Rio Grande do Sul & 311 & 354 & Observational & $\mathrm{N}$ & 7 \\
\hline Henkes $^{44}$ & Santa Cruz do Sul, Rio Grande do Sul & 376 & 350 & Observational & $\mathrm{Y}$ & 4 \\
\hline Miodutzki ${ }^{45}$ & São Bento do Sul, Santa Catarina & 60 & & Observational & Y & 4 \\
\hline Montoro ${ }^{46}$ & Florianópolis, Santa Catarina & 46 & 47 & Observational & $\mathrm{Y}$ & 5 \\
\hline Nogueira $^{47}$ & Fortaleza, Ceará & 108 & 236 & Observational & $\mathrm{N}$ & 7 \\
\hline Oliveira $^{33}$ & Porto Alegre, Rio Grande do Sul & 48 & 40 & Quasi-experimental & $\mathrm{N}$ & 5 \\
\hline Pelegrini ${ }^{48}$ & Brazil & 3.393 & 4.114 & Observational & Y & 6 \\
\hline Pelicer $^{49}$ & José Bonifácio, São Paulo & 320 & 328 & Observational & $\mathrm{Y}$ & 4 \\
\hline Pereira $^{50}$ & Uruguaiana, Rio Grande do Sul & 751 & 714 & Observational & $\mathrm{Y}$ & 6 \\
\hline Petry $^{51}$ & Florianópolis, Santa Catarina & 61 & 29 & Observational & $\mathrm{Y}$ & 4 \\
\hline Reuter $^{52}$ & Santa Cruz do Sul, Rio Grande do Sul & 686 & 568 & Observational & $\mathrm{Y}$ & 4 \\
\hline Schubert ${ }^{53}$ & Londrina, Paraná & 165 & 236 & Observational & $\mathrm{Y}$ & 5 \\
\hline Silva $^{15}$ & Curitiba, Paraná & 24 & 14 & Observational & $\mathrm{N}$ & 4 \\
\hline \multicolumn{7}{|c|}{ Skills-related Physical Fitness } \\
\hline Souza Bezerra ${ }^{14}$ & Manaus, Amazonas & 40 & & Observational & $\mathrm{N}$ & 4 \\
\hline Moreira $^{13}$ & Ubá, Minas Gerais & 22 & & Observational & Y & 5 \\
\hline Silva $^{15}$ & Curitiba, Paraná & 24 & 14 & Observational & $\mathrm{N}$ & 5 \\
\hline
\end{tabular}

$\mathrm{n}=$ number of participants; $\mathrm{Y}=$ yes; $\mathrm{N}=$ no; $\mathrm{F}=$ female; $\mathrm{M}=$ male; $¥=\mathrm{PROESP}-\mathrm{Br}$ criteria included; $\star$ = methodological quality final score.

to the high variability of the participants, Souza Bezerra et al. ${ }^{14}$ describe and compare the physical fitness of children who attended an indoor soccer school with children's who attended structured physical education classes. The study of Silva et al. ${ }^{15}$ was the only one that described all variables stratified by sex.

\section{Discussion}

In summary, the results highlighted an elevated proportion of Brazilian children and adolescents with low cardiovascular fitness, which has been associated with the occurrence of high cholesterol levels, hypertension and insulin resistance ${ }^{16-18}$. The same scenario was observed for the musculoskeletal parameters (FLEX and MST), which have been associated with the occurren- ce of low back pain and hyperlordosis ${ }^{19}$. The few studies evaluating motor performance made the synthesis of the results inconsistent.

According to some research, the evaluation of the nutritional status allows the identification of the main risks for cardiometabolic diseases ${ }^{17,20,21}$. Our results related to cardiovascular health (BMI and CRF) showed that approximately $27-30 \%$ of the adolescents, boys and girls, were classified in the overweight/obesity categories or the health risk zone for the BMI.

Those results are similar to other studies conducted in the USA and Europe, which identified 30\% of the adolescents with overweight/obesity ${ }^{22,23}$. In a recent study, Gaya et al. ${ }^{24}$, highlighted the rising cardiometabolic and musculoskeletal health risk from 2008/09 to 
Table 2 - Brazilian children and adolescent physical fitness related to health.

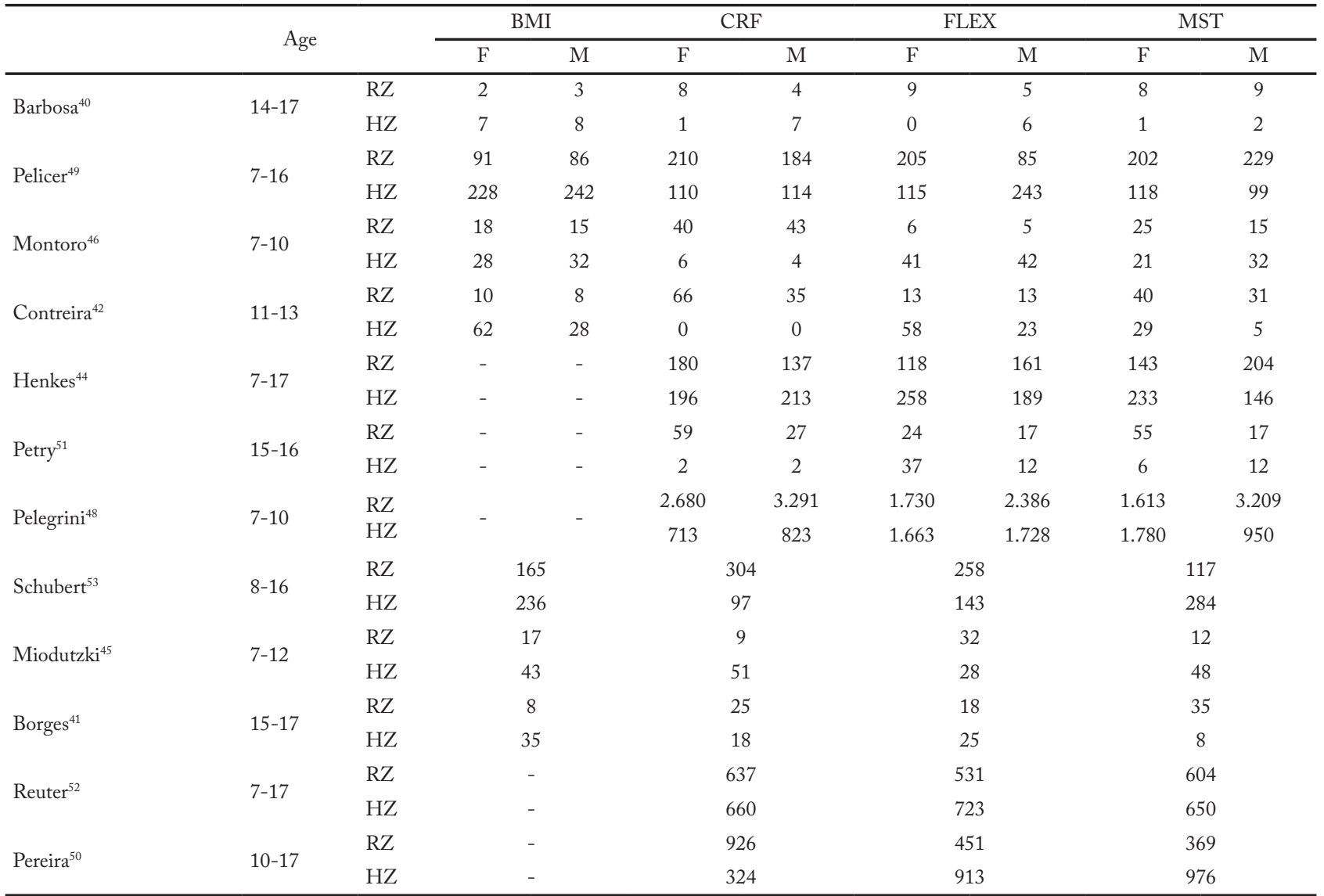

$\mathrm{BMI}=$ body mass index $\mathrm{CRF}=$ cardiorespiratory fitness; FLEX = flexibility; MST = local muscle strength/resistance; F = female; M: male; $\mathrm{ZR}$ health risk zone; $\mathrm{ZS}$ healthy zone.

Table 3 - Brazilian children and adolescent physical fitness related to health.

\begin{tabular}{lccccccccc}
\hline & Age & \multicolumn{2}{c}{ BMI } & \multicolumn{2}{c}{ CRF } & \multicolumn{2}{c}{ FLEX } & \multicolumn{2}{c}{ MST } \\
\cline { 2 - 10 } & & F & M & F & M & F & M & F & M \\
\hline Dumith $^{43}$ & $7-15$ & 19.7 & 19.4 & 1018 & 1261 & 22.5 & 18.6 & 23.9 & 31.4 \\
Nogueira $^{47}$ & $11-16$ & 19.0 & 18.5 & 1278.4 & 1535.8 & 26.2 & 23 & 27.9 & 35.6 \\
Silva $^{15}$ & \pm 16 & 21.76 & 21.01 & 936.96 & 1140.0 & 25.83 & 19.57 & 26.67 & 33.86 \\
Oliveira $^{33}$ & \pm 14 & 20.46 & 21.35 & 940.73 & 1123.07 & 32.08 & 22.78 & 36.40 & 46.15 \\
\hline
\end{tabular}

$\mathrm{BMI}=$ body mass index; $\mathrm{CRF}=$ cardiorespiratory fitness FLEX = flexibility; $\mathrm{MST}=$ local muscle strength/resistance; $\mathrm{F}=$ female; $\mathrm{M}=$ male .

2013/14 among Brazilian adolescents, pointing out an alarming scenario once the high BMI levels and their related health issues.

Studies have emphasized that a bigger health risk is added when the low CRF is associated with an overweight/obesity status ${ }^{20,25}$. Therefore, the results of this present review indicate that beyond the high prevalence of BMI risk, Brazilian adolescent presents also a high prevalence of risk related to $\mathrm{CRF}$, with approximately $70 \%$ of the evaluated participants at the health risk zone. The significance of a concerned look to our results is justified by the fact, in addition to those already mentioned, that Ortega et $\mathrm{al}^{25}$ and Lee et al. ${ }^{26}$ have suggested the CRF as one of the main markers of physical fitness related to health in youth. In addition, a recent systematic review concluded that higher CRF in childhood and adolescence is associated with lower BMI, body fatness, and metabolic syndrome incidence at least 2 years later ${ }^{27}$.

Results related to musculoskeletal health indicate that $50 \%$ of the participants are at the health risk zone for FLEX and $65 \%$ are in the same situation for the 
Table 4-Brazilian children and adolescent physical fitness related to skills.

\begin{tabular}{|c|c|c|c|c|c|c|c|}
\hline \multicolumn{3}{|c|}{ Age } & UES & LES & AGI & SPD & CRF \\
\hline \multirow{2}{*}{$\begin{array}{l}\text { Souza } \\
\text { Bezerra }^{14}\end{array}$} & $10-11$ & $\mathrm{PE}$ & 2.35 & 1.33 & 4.95 & 4.36 & 1072 \\
\hline & & FUT & 1.93 & 1.47 & 4.49 & 3.98 & 940 \\
\hline \multirow[t]{5}{*}{ Silva ${ }^{15}$} & $\pm 15,92$ & $\mathrm{~F}$ & 3.41 & 1.32 & 7.35 & 4.35 & 936.96 \\
\hline & & M & 4.55 & 1.82 & 6.43 & 3.72 & 1140 \\
\hline & & & $\mathrm{n}$ & $\mathrm{n}$ & $\mathrm{n}$ & $\mathrm{n}$ & $\mathrm{n}$ \\
\hline & & Weak & 13 & 1 & 14 & 1 & 0 \\
\hline & & Regular & 1 & 3 & 7 & 0 & 0 \\
\hline \multirow[t]{3}{*}{ Moreira $^{13}$} & $11-16$ & Good & 2 & 10 & 1 & 4 & 0 \\
\hline & & Very Good & 6 & 7 & 0 & 12 & 3 \\
\hline & & Excellence & 0 & 1 & 0 & 5 & 19 \\
\hline
\end{tabular}

UES = upper limbs explosive strength; LES = lower limbs explosive strength; AGI = agility; SPE = speed CRF = cardiorespiratory fit ness; $\mathrm{F}$ = female; $\mathrm{M}=$ male $; \mathrm{PE}=$ physical education; $\mathrm{FUT}=$ football.

MST. This enormous number of children and adolescents with low scores for both musculoskeletal indexes may be related to an inactive lifestyle, as observed with other health indicators.

The results highlighted in this review corroborate the international literature, and with research that specifically demonstrated that, variables like FLEX and MST have a strong relation with musculoskeletal diseases, being an important indicator of musculoskeletal health ${ }^{19,25,28}$. Based on these studies, the results of this present review suggest a high risk for musculoskeletal for Brazilian children and adolescents.

Lower back, neck and shoulder pain, which affect the lumbar spine, are the most common related musculoskeletal disorders ${ }^{29}$, and approximately $80 \%$ of the general population is affect by these disorders throughout life. Gasibat, Simbak and Aziz ${ }^{29}$ reviewed the literature to elucidate the effects of stretching on musculoskeletal disorders and evidenced that the performance of stretching exercises can contribute to reduce discomfort/pain and increase range of motion.

Besides et al. ${ }^{8}$, in reviewing the literature regarding the benefits of physical activity and fitness of children and adolescents, concluded that even modest amounts of physical activity can have health benefits for young people in the health risk zone (for example, obesity, high pressure). Aerobic activities have the greatest health benefits, except for bone health; in this case, activities that impact the musculoskeletal system ${ }^{8}$ are needed.

We underline that more than half of the Brazilian youth may be at premature risk for cardiovascular and musculoskeletal problems that can turn up in the future into a serious problem to the public health system ${ }^{28,30}$. In other words, there is a direct cost related to public health expenses with treatment for patients and their families, prevention and diagnosis, and an indirect cost (e.g., the impact at leisure time and absenteeism), with great sacrifice for family and friends to support that patient ${ }^{31}$.

It becomes evident that BMI, CRF, FLEX and MST are significant health indicators that can be influenced by regular structured exercise. Andersen et al. ${ }^{32}$ and Oliveira et al. ${ }^{33}$ showed an existing strong relationship between leisure and PE exercise with the health-related fitness. Taking all the evidence into consideration, PE can and must be a valuable tool in health promotion among children and adolescents ${ }^{4,34}$.

Results related to skills-related fitness are still not consistent for this review. Only three studies used the full PROESP-Br battery tests and measures and had a high methodological quality. Therefore, we refer first the necessity and suggest that further studies should be carried out to describe a complete profile of the skills-related fitness of Brazilian children and adolescents.

Some Brazilian studies demonstrate that the adolescent skills-related fitness does not reach adequate levels, reporting performances considered weak or regular accounting for $40 \%$ of the population ${ }^{35,36}$. The PROESP$\mathrm{Br}$ research group presented pieces of evidence that approximately $30-40 \%$ of the boys and $36-44 \%$ of the girls are classified as poor performers in at least one variable of the skills-related fitness ${ }^{37}$ (this study did not evaluate the adolescent CRF). The explosive strength had a better prevalence for excellent performances (4\%), followed by agility (3\%) and speed (1-2\%).

Therefore, the early identification and treatment of youth with low levels of muscular fitness (push-ups, sit-ups, bent arm hang, handgrip, standing long jump, vertical jump, etc.) could improve long-term health outcomes, since the prevention of chronic diseases should start as early in life as possible ${ }^{9}$. Some studies reported that variables like lower and upper limbs strength, speed and agility are important capacities for the maintenance of a systematic sports practice ${ }^{6}$. In contrast, low levels of skills-related fitness stands to output kids and adolescents away from sports and physical practices, decreasing their opportunities to enhance motor, cognitive and social abilities. In this perspective, Mello et al. ${ }^{36,37}$ argue that this situation may cause a decrease at the physical activity levels, and consequently, increase the risk of developing health problems related to sedentary behaviour.

Eime et al. ${ }^{38}$ highlight that there is substantial evi- 
dence of many different psychological and social health benefits of participation in sports by children and adolescents. More specifically, there are reports that participation in team sports rather than individual activities is associated with better health. It is conjectured that this is due to the social nature of team sport and that the health benefits are enhanced through positive involvement of peers and adults ${ }^{38}$.

We emphasize that in the skills-related fitness context it is possible and recommended to identify children and adolescents with excellent levels of physical fitness. This performance level indicates high motor skills, and excellent levels of strength, speed, agility and endurance tests can configure a skills-related fitness pattern for specific sports modality ${ }^{39}$. In this matter, authors ${ }^{39}$ advocated the school community need to recognize the talent as part of human diversity and realize that identifying and supporting them properly is a school concern. Beyond the need to identify and support them appropriately, when it comes specifically to motor skills, it is necessary to offer and support sports programs that are available for young athletes.

To our knowledge, this is the first systematic review that followed PRISMA recommendations concerning the revised theme, that is, to delineate the population physical fitness profile. This systematic review has practical implications to professionals and strengths: a) to screen for conditions that may affect students' general health; b) to identify deficiencies at the different components of skills; c) to establish reference values before initiate an exercise program; d) to monitoring the development of the class or training group; e) to give better exercise recommendations about health promotion or an adequate sports performance; and $\mathrm{f}$ ) to present a national profile from the same evaluation method, decreasing the method heterogeneity.

This study also has limitations: a) the heterogeneity in the studies sample number; b) studies not developed in different regions of Brazil, there is an evidence concentration in south and north regions; c) a small number of studies that evaluated skills-related physical fitness; and d) the role of potential confounders in the profile-analysis from cross-sectional studies (e.g., total physical activity and maturation level).

In conclusion, the results indicate low cardiovascular health (BMI/CRF), mainly related to the cardiorespiratory component, and low musculoskeletal health (FLEX/MST) among Brazilian children and adolescents. We emphasize the lack of studies related to motor performance that make it impossible to delineate the Brazilian population profile, pointing out that this construct has been little explored by physical education teachers.

\section{Conflict of interest}

The authors declare no conflict of interest.

\section{Author's contributions}

The authors Pedretti A, Mello JB, Gaya AR, Pedretti A and Gaya A, declare to be responsible for the elaboration of the manuscript entitled "Health- and skill-related physical fitness profile of Brazilian children and adolescent: a systematic review", with the first two authors participating at the project elaboration, data collection, data analysis and article writing, and the third, fourth and fifth authors participating at the orientation and revision of all stages of the study.

\section{Acknowledgements}

Conselho Nacional de Desenvolvimento Científico e Tecnológico (CNPq) and Coordenação de Aperfeiçoamento de Pessoal de Nivel Superior (CAPES).

\section{References}

1. Gaya A. Mas afinal, o que é Educação Física? Movimento (UFRGS ONLINE). 1994;1(1):29-34.

2. Brasil. Pesquisa nacional de saúde do escolar: 2015. 1th ed. Rio de Janeiro: IBGE; 2016. [citado em 2020 abr 29]. Disponível em: https://biblioteca. ibge. gov. br/visualizacao/ livros/liv97870. pdf.

3. Brasil. Relatório de desenvolvimento humano nacional movimento é vida: atividades físicas e esportivas para todas as pessoas: 2017. 1th ed. Brasília: PNUD; 2017. [citado em 2020 abr 29]. Disponível em: http://movimentoevida. org/ wp-content/uploads/2017/09/PNUD_RNDH_completo. pdf.

4. U. S. Department of Health and Human Services, Centers for Disease Control and Prevention, National Center for Chronic Disease Prevention and Health Promotion and Division of Adolescent and School Health Strategies to Improve the Quality of Physical Education: United States 2010 [citado em 2020 abr 29] Disponível em: https:// wwwcdcgov/healthyschools/pecat/quality_pe.pdf.

5. Lloyd RS, Oliver JL. The youth physical development model: A new approach to long-term athletic development. Strength Cond J. 2012;34(3):61-72.

6. Lloyd RS, Oliver JL, Radnor JM, Rhodes BC, Faigenbaum AD, Myer GD. Relationships between functional movement screen scores, maturation and physical performance in young soccer players. J Sports Sci. 2015;33(1):11-9.

7. World Health Organization. Global recommendations on physical activity for health: Switzerland. 2010. [citado em 2020 abr 29]. Disponível em: https://apps. who. int/ iris/bitstream/handle/10665/44399/9789241599979_eng. pdf? sequence $=1$. 
8. Janssen I, LeBlanc AG. Systematic review of the health benefits of physical activity and fitness in school-aged children and youth. Int J Behav Nutr Phy. 2010;7:40.

9. García-Hermoso A, Ramírez-Campillo R, Izquierdo M. Is muscular fitness associated with future health benefits in children and adolescents? A systematic review and metaanalysis of longitudinal studies. Sports Med. 2020;174:6.

10. PROESP-Br. Manual de testes e avaliação: 2016. 5th ed. Porto Alegre: PROESP-Br; 2016. [citado em 2020 abr 28]. Disponível em: https://www. ufrgs. br/proesp/arquivos/ manual-proesp-br-2016. pdf

11. Moher D, Liberati A, Tetzlaff J, Altman DG, Group P. Preferred reporting items for systematic reviews and metaanalyses: the PRISMA statement. PLoS Med. 2009;6:7.

12. Ottawa Hospital Research Institute. The Newcastle-Ottawa Scale (NOS) for assessing the quality of nonrandomised studies in meta-analyses: Canada. 2014. [citado em $2020 \mathrm{abr}$ 29]. Disponível em: http://www. ohri. ca/programs/clinical_ epidemiology/oxford. asp.

13. Moreira CD, Sperandio BB, de Almeida TF, Ferreira EF, Soares LA, de Oliveira RAR. Nível de aptidão física para o desempenho esportivo em participantes adolescentes do projeto esporte em ação. Rev Bras Prescrição Fisiol Exerc. 2017;11(64):74-82.

14. Souza-Bezerra E, Machado JCBP, Benarros M, Rossato M. Diferenças entre capacidades físicas de crianças praticantes de futsal e da Educação Física. Lect Educ Fís. 2013;18:183.

15. Silva LVM, Packe C, Tkac C, Braga RK, Urbinati KS. Associação entre variáveis de composição corporal e aptidão física em adolescentes. Rev Atenção Saúde. 2014;12(41):363-6.

16. Bergmann GG, Gaya A, Halpern R, Bergmann ML, Rech $\mathrm{RR}$, Constanzi CB, et al. Circunferência da cintura como instrumento de triagem de fatores de risco para doenças cardiovasculares em escolares. J Pediatr. 2010;86(5):411-6.

17. Bergmann GG, Gaya A, Halpern R, Bergmann M, Rech RR, Constanzi $\mathrm{CB}$, et al. Índice de massa corporal para triagem de fatores de risco para doenças cardiovasculares na infância. Arch Endocrinol Metab. 2011;55(2):114-20.

18. Bergmann GG, Gaya ACA, Halpern R, de Araújo Bergmann ML, Rech RR, Constanzi CB, et al. Pontos de corte para a aptidão cardiorrespiratória e a triagem de fatores de risco para doenças cardiovasculares na infância Cardiorespiratory fitness cut offs points and cardiovascular risk factors screening at infancy. Rev Bras Med Esporte. 2010;16(5):339-43.

19. Dorneles RCG, Oliveira HLR, Bergmann MLA, Bergmann GG. Flexibility and muscle strength/resistance indicators and screening of low back pain in adolescents. Rev Bras Cineantropom Desempenho Hum. 2016;18(1):93-102.

20. Abbasi F, Blasey C, Reaven GM. Cardiometabolic risk factors and obesity: does it matter whether BMI or waist circumference is the index of obesity? Am J Clin Nutr. 2013;98(3):637-40.

21. Savva SC, Lamnisos D, Kafatos AG. Predicting cardiometabolic risk: waist-to-height ratio or BMI. A metaanalysis. Diabetes Metab Syndr Obes. 2013;6:403-19.

22. Ahrens W, Pigeot I, Pohlabeln H, De Henauw S, Lissner L, Molnár D, et al. Prevalence of overweight and obesity in European children below the age of 10. Int J Obes. 2014;38(supp12):99-107.

23. Ogden CL, Carroll MD, Lawman HG, Fryar CD, KruszonMoran D, Kit BK, et al. Trends in obesity prevalence among children and adolescents in the United States, 1988-1994 through 2013-2014. JAMA. 2016;315(21):2292-9.
24. Gaya AR, Dias AF, Lemes VB, Goncalves JC, Marques PA, Guedes G, et al. Aggregation of risk indicators to cardiometabolic and musculoskeletal health in Brazilian adolescents in the periods 2008/09 and 2013/14. J Pediatr. 2018;94(2):177-83.

25. Ortega FB, Tresaco B, Ruiz JR, Moreno LA, Martin-Matillas M, Mesa JL, et al. Cardiorespiratory fitness and sedentary activities are associated with adiposity in adolescents. Obesity. 2007;15(6):1589-99.

26. Lee D, Artero EG, Sui X, Blair SN. Mortality trends in the general population: the importance of cardiorespiratory fitness. J Psychopharmacol. 2010;24(supp14):27-35.

27. Mintjens S, Menting MD, Daams JG, van Poppel MN, Roseboom TJ, Gemke RJ. Cardiorespiratory fitness in childhood and adolescence affects future cardiovascular risk factors: a systematic review of longitudinal studies. Sports Med. 2018;48(11):2577-605.

28. Ebbeling CB, Pawlak DB, Ludwig DS. Childhood obesity: public-health crisis, common sense cure. Lancet. 2002;360(9331):473-82.

29. Gasibat Q, Simbak NB, Aziz A, Petridis L, Tróznai Z. Stretching exercises to prevent work-related musculoskeletal disorders: A review article. AJSSM. 2017;5(2):27-37.

30. Daniels SR, Jacobson MS, McCrindle BW, Eckel RH, Sanner BM. American Heart Association Childhood Obesity Research Summit Executive Summary. Circulation. 2009;119(15):2114-23.

31. Pereira J, Mateus C. Custos indirectos associados à obesidade em Portugal. Rev Port Saúde Pública. 2003;22(3):65-80.

32. Andersen LB, Lauersen JB, Brønd JC, Anderssen SA, Sardinha LB, Steene-Johannessen J, et al. A new approach to define and diagnose cardiometabolic disorder in children. J Diabetes Res. 2015;2015:539835.

33. Oliveira L, Braga F, Lemes V, Dias A, Brand C, Mello J, et al. Effect of an intervention in Physical Education classes on health related levels of physical fitness in youth. Rev Bras Ativ Fís Saúde. 2017;22(1):46-53.

34. Commonwealth of Australia. Independent Sports Panel - The Future of Sport in Australia: Australia. 2009. [citado em 2020 abr 29]. Disponível em: https://www. sportdevelopment. org. uk/index. php/subjects/59-international-documents/790crawford-report.

35. Dumith SC, Ramires VV, Souza MJA, Moraes DS, Petry FG, Oliveira ES, et al. Aptidão física relacionada ao desempenho motor em escolares de sete a 15 anos. Rev Bras Educ Fís Esporte. 2010;24(1):5-14.

36. Mello JB, da Silva Hernandez M, Farias VM, dos Santos Pinheiro E, Bergmann GG. Aptidão Física relacionada ao desempenho motor de adolescentes de Uruguaiana, Rio Grande do Sul. Rev Bras Ciênc Mov. 2015;23(4):72-9.

37. Mello JB, Nagorny GAK, Haiachi MDC, Gaya AR, Gaya ACA. Projeto Esporte Brasil: physical fitness profile related to sport performance of children and adolescents. Braz J Kinathrop Hum Perform. 2016;18(6):658-66.

38. Eime RM, Young JA, Harvey JT, Charity MJ, Payne WR. A systematic review of the psychological and social benefits of participation in sport for children and adolescents: informing development of a conceptual model of health through sport. Int J Behav Nutr Phy. 2013;10:98.

39. Gaya A, Gonçalves da Silva G, Cardoso M, Torres L. Talento esportivo: estudo de indicadores somato-motores na seleção para o desporto de excelência. Perfil. 2002;6(6):86-96. 
40. Barbosa T, Zica M, Quaresma F, Sonati J, Maciel E. Relação entre composição corporal e aptidão física em grupo de escolares do ensino médio no Brasil. Revista da UIIPS. 2016;4(2):273-84.

41. Borges FMR, Marchesan M, de Rosso Krug R, Rossato VM. Relação da Educação Física com a Aptidão Física e com Desempenho Escolar de Alunos do Ensino Médio. Biomotriz. 2016;10(2):112-28.

42. Contreira AR, Pizzo GC, da Rocha FF, Lazier-Leão TR, Caruzzo AM, Copetti F, et al. Perfil de Aptidão Física Relacionada à Saúde em Adolescentes. Saúde e Pesquisa. 2016;9(2):309-15.

43. Dumith $\mathrm{C}$, Azevedo Júnior MR, Rombaldi AJ. Aptidão física relacionada à saúde de alunos do ensino fundamental do município de Rio Grande, RS, Brasil. Rev Bras Med Esporte. 2008;14(5):454-9.

44. Henkes CM, Borfe L, Muradás R, Tornquist L, Burgos MS. Aptidão física relacionada ao desempenho de escolares: estudo comparativo dos hemisférios norte-sul-leste-oeste da zona rural de Santa Cruz do Sul-RS. Cinergis. 2013;14(4):206-9.

45. Miodutzki A, de Souza WC, Grzelczak MT, Mascarenhas LPG. Antropometria e aptidão física: comparação entre praticantes e não praticantes de escolinhas esportivas. Arch Health Invest. 2016;5(4):192-6.

46. Montoro APPN, Leite CR, Espíndola JA, Alexandre JM, da Silva Reis M, Capistrano R, et al. Aptidão física relacionada à saúde de escolares com idade de 7 a 10 anos. ABCS Health Sciences. 2016;41(1):29-33.
47. Nogueira JAD, Pereira CH. Aptidão física relacionada à saúde de adolescentes participantes de programa esportivo. Rev Bras Educ Fís Esporte. 2014;28(1):31-40.

48. Pelegrini A, Silva DAS, Petroski EL, Glaner MF. Healthrelated physical fitness in Brasilian schoolchildren: data from the Brazil sport program. Rev Bras Med Esporte. 2011;17(2):92-6.

49. Pelicer FR, Nagamine KK, Faria MA, de Lima Freitas V, Neiva CM, Pessôa Filho DM, et al. Heath-Related Physical Fitness in School Children and Adolescents. Int J Sports Sci. 2016;6(1):19-24.

50. Pereira TA, Bergmann MLdA, Bergmann GG. Factors associeted with low physical fitness in adolescents. Rev Bras Med Esporte. 2016;22(3):176-81.

51. Petry K, Fachineto $\mathrm{S}$. Aptidão física relacionada à saúde e condição econômica de alunos do ensino médio de uma escola estadual de Florianópolis, SC. Lect Educ Fís. 2012;165:16.

52. Reuter CP, Doern R, da Silva CF, Marques KC, Welser L, da Silva R, et al. Health-related physical fitness and sociodemographic factors: a study with schoolchildren from Santa Cruz do Sul-RS. Cinergis. 2016;17(2):43-7.

53. Schubert A, Januário RSB, Casonatto J, Sonoo CN. Aptidão Física relacionada à Prática Esportiva em Crianças e Adolescentes. Rev Bras Med Esporte. 2016;22(2):142-6.

Received: $13 / 04 / 2020$

Approved: 02/09/2020

\section{Quote this article as:}

Pedretti A, Mello JB, Gaya AR, Pedretti A, Gaya A. Health-and skill-related physical fitness profile of Brazilian children and adolescent: a systematic review. Rev Bras Ativ Fis Saúde.2020;25:e0131. DOI: 10.12820/rbafs.25e0131 